\title{
Purchasing Social Responsibility Activities in Malaysia: A focus in Labour, Health, and Safety
}

\author{
Saw Khuan Loo \\ School of Business and Administration, Wawasan Open University, \\ 54, Jalan Sultan Ahmad Shah, 10050 Penang, Malaysia, \\ E-mail: skloo@wou.edu.my (Corresponding Author) \\ Ellisha Nasruddin \\ Graduate School of Business, Universiti Sains Malaysia, \\ 11800 Penang, Malaysia \\ E-mail: ellisha@usm.my
}

\begin{abstract}
Globalisation of companies has led to international purchasing trend with multiple suppliers worldwide. However there were many issues pertaining to labour and health \& safety of Asian suppliers. The purchasing function or professionals (purchasing managers) have the most interfaces and influences to suppliers and they are capable to play the most important role in suppliers' labour issues. This qualitative, transcendental phenomenological study describes the experience of purchasing managers with regard to purchasing social responsibility (PSR) activities in labour, health and safety. In depth interviews were conducted with 16 purchasing managers working in electrical and electronics multinational corporations located in northern region of Malaysia. There are eight core themes described the nature of PSR activities experienced by purchasing managers. First, EICC code enhances PSR activities but labour standards are new and less priority than health and safety. Second, purchasing managers working in American based electrical and electronics multinational corporations are more experience in PSR activities compared with purchasing managers working in corporations with headquarters in other countries. Third, supplier audit is the most common PSR activity but it was only conducted for critical suppliers. Fourth, supplier selfassessment triggers supplier audit or improvement plan. Fifth, supplier selection only requires basic compliance in labour, health and safety standards. Sixth, short training of labour, health and safety standards is commonly arranged for all suppliers. Seventh, corrective actions are used to manage suppliers' labour violations in occupational safety, wages, working hours, dormitories and holding of migrant passports. Eighth, issues encountered with suppliers on PSR activities included labour standards increase material pricing, suppliers reluctant to adhere to labour standards and workers preferred longer work hours in order to gain higher wages.
\end{abstract}

Keywords: purchasing social responsibility activities, phenomenological interviews, electrical, electronics, labour, health and safety.

\section{INTRODUCTION}

Purchasing function's involvement in suppliers' CSR is called Purchasing social responsibility (PSR) (Carter \& Jennings, 2000, 2004). PSR activities refer to the purchasing activities or practices related to suppliers' CSR. PSR activities may include supplier audits, supplier selection, supplier contract, supplier training, etc. Previous research found that there was issue of fraud supplier audits for Asian supply chain in the perspectives of factory managers, CSR experts and CSR managers (Welford \& Frost, 2006). However these fraud supplier audits was not mentioned in previous case study researches of PSR activities which conducted in IKEA and Marks \& Spencer (Andersen \& Skjoett-Larsen, 2009; Johnson, 2004). This mixed result poses a research gap for further studies in PSR activities.

There were labour issues reported in the supply chain of South East Asia which included Malaysia (Bormann et al., 2010; Jiang, 2009; Welford \& Frost, 2006). The labour issues reported included sub-standard living quarters, excessive working hours and late payment of wages. However only few researches were done in Asian context about purchasing function's involvement or PSR though purchasing function (Antonio, 2011; Lillywhite, 2007) has the most influence in suppliers' CSR. Thus, there is lack of research of PSR activities focuses on labour issues in Asian countries and Malaysia in particular.

The previous researches identified and explained briefly the variables or aspects of PSR activities for companies under the case studies (Andersen \& SkjoettLarsen, 2009; Johnson, 2004). However, there is lack of research pertaining to how purchasing managers directly experience the PSR activities in labour standards and health \& safety though purchasing managers are the closest interface with suppliers. A qualitative phenomenology approach is lacking to explore the essence of purchasing managers' lived experience in PSR activities.

\section{LITERATURE REVIEW}

\subsection{Purchasing social responsibility (PSR)}

Purchasing social responsibility is the involvement of purchasing function in corporate social responsibility (CSR) as defined by Carter and Jennings (2000, 2004). PSR is also called socially responsible purchasing, ethical sourcing or CSR in Purchasing. That means PSR is related to CSR and originated from CSR. CSR is now expected by the stakeholders such as customers, investors, shareholders, NGOs, regulatory agencies, and the media (Carter \& Jennings, 2000; Ki-Hoon \& Ji-Whan, 2009). However, due to globalisation and outsourcing trend, companies purchase raw materials or products from many suppliers in different 
parts of the world. The business trend now is many global brands do not own any manufacturing operations as they outsource the manufacturing to their contracting companies or contract manufacturers. Good examples of these are Apple, H \& M and IKEA. Thus, they are closely associated with their suppliers' operations. This makes companies to be responsible for their suppliers' CSR because they will get affected if their suppliers do not perform well in CSR (Andersen \& Skjoett-Larsen, 2009; Eltantawy, Fox, \& Giunipero, 2009; Ki-Hoon \& Ji-Whan, 2009; Maignan, Hillebrand, \& McAlister, 2002; Spence \& Bourlakis, 2009). It means they have to manage suppliers' CSR at global level (Ki-Hoon \& Ji-Whan, 2009). Thus, it was also mentioned that large scale companies should support SMEs in CSR activities (Ciliberti, et al., 2009)

The previous PSR researches included PSR dimensions, PSR drivers, PSR barriers, and PSR activities. Carter \& Jennings $(2004,2000)$ initiated researches in United States on the aspects of PSR dimensions, drivers and barriers. The research on PSR dimensions was followed by Antonio in Hong Kong/ Pearl River. The research on PSR drivers was then followed by Oksana \& Charlotte (2009) in Sweden and replicated by Salem (2009) in Thailand. Carter \& Jenning's $(2004,2000)$ research on PSR barriers was followed by both Oksana \& Charlotte (2009) in Sweden and Antonio in Hong Kong / Pearl River (2011). However the findings from the abovementioned researches were varied by regions and countries. The different findings pose more PSR researches in other countries.

\subsection{Purchasing Social Responsibility (PSR) Activities}

PSR activities are related to PSR and a subset to PSR. PSR activities are purchasing practices incorporated with CSR. Also, PSR activities are the purchasing practices related to suppliers' corporate social responsibility. Purchasing social responsibility activities may consist of supplier audit, supplier selection, supplier monitoring, contract signing, training and education, rewards and partnership with regards to suppliers' CSR. Different researchers may also call PSR activities in different terms such as social responsible purchasing (Maria, 2010), socially responsible buying practices (Maignan \& McAlister, 2003), supplier measurement (Novak, 2004), sourcing initiatives or ethical sourcing programs (Johnson, 2004). There is lack of research to study PSR activities for individual countries in Asia region. There was a research conducted for several countries in Asia mentioned about issues of cheatings, fraud, and flawed methodology in supplier audit. Also the research was done in the perspective of CSR managers, CSR experts, and factory managers/owners, but not purchasing managers (Welford \& Frost, 2006). The above research did not mention about purchasing managers' perspectives in the supplier audits though purchasing function is the most important interface with suppliers as mentioned by C. R. Carter \& Jennings (2000, 2004). Thus, there is research gap to study the nature of PSR activities from the perspective of purchasing managers. In fact, there were case study research of PSR activities done in other Western countries for IKEA and Marks \& Spencer (Andersen \& Skjoett-Larsen, 2009; Johnson, 2004; Maria, 2010) but supplier audits was not an issue as what mentioned in Asian supply chain (Welford \& Frost, 2006). This could imply that the abovementioned researches may not be applicable to other companies and countries. Thus, there is research gap to study the issues of PSR activities for individual countries in Asian region.

There is a research gap to focus on labour standards and health \& safety in PSR activities because there were numbers of labour issues in Malaysia as reported in previous researches. The labour issues reported in Malaysia were poor accommodation, lack of hygiene, work permit issues, unequal treatment, wage discrimination, non-payment of wages, long working hours, no freedom of association and together with other health, safety and human right issues (Amnesty, 2010; Bormann, et al., 2010; E. Devadason, 2011; E. S. Devadason \& Meng; Hill, 2012; Kanapathy \& Office, 2008; Malaysia, 2009; Nike, 2007-9; Wahyono, 2005/2006). This is in line with the previous research which mentioned that purchasing managers need to pay more attention to suppliers' labour issues (Antonio, 2011). This is also in line with what Novak (2004) suggested that there was a need to focus on individual dimension of PSR. In addition, there were conceptual researches mentioned that companies might be proactive in one dimension of PSR such as environmental but reactive in another dimension such as labour standards (Maignan, et al., 2002; Maignan \& McAlister, 2003). PSR activities focused on environment or green purchasing researches has been done in Malaysia (Eltayeb \& Zailaini, 2009) but there is lack of research on PSR activities focused on labour, health and safety. Thus, there is a need to focus on labour and health and safety dimension in research of PSR activities. The labour standards include freely chosen employment, child labour avoidance, working hours, wages and benefits and human treatment, non-discrimination and freedom of association. The health \& safety standards include occupational safety, emergency preparedness, occupational injury and illness, industrial hygiene, physical demanding work, machine safeguarding, sanitation, food, and housing (EICC).

\subsection{The Method}

3. METHODOLOGY

This research used qualitative transcendental phenomenological approach from Moustakas (1994) to study the lived experiences of purchasing managers working in electronics/electrical industry in Penang, Malaysia. The research used semi-structured, audio recorded and in-depth transcribed interview to investigate the central phenomenon that involves purchasing managers' (participants) lived experiences of PSR activities in labour and health \& safety. The participants were purposefully selected from electrical and electronics multinational companies in northern Malaysia.

The phenomenological method is suitable for this new research topic in Malaysia as it helps the researcher to put aside the assumptions about the phenomenon and see it afresh (King \& Horrocks, 2010). Furthermore, most of the previous researches in PSR activities in other countries did not focus on purchasing managers' actual lived experiences in these activities (Andersen \& Skjoett-Larsen, 2009; Johnson, 2004). It is because the previous case studies might cause the researchers to focus on the case as a company or unit rather than lived experience of managers involved in 
PSR activities. Carter \& and Jennings (2000) mentioned that purchasing managers should build upon their experience in one area of PSR such as environment purchasing activities. However, so far there is lack of research exploring purchasing managers' lived experience in PSR activities of labour and health \& safety. Thus, this research is to add value by focusing on purchasing managers' deeper experiences with regards to PSR activities in labour and health \& safety. The lived experience of phenomenological approach emphasize on direct experience and subjective experience of PSR activities from purchasing managers. Also it is the opposite of second hand experience, theoretical explanation or abstract philosophical concept (Creswell, 2007; Patton, 2002; Taves, 2003).

There are four processes in phenomenological research which consists of epoche, phenomenological reduction, imaginative variation and synthesis (Moustakas, 1994). This research applied all these four processes. This research involved the process of "epoche" as mentioned by Moustakas (1994) so that it will be completely open, receptive and naïve in listening to research participants' description of their PSR activities in labour and health \& safety. It means refrain from judgments and abstain from ordinary way of perceiving things. This research involved the process of "epoche" as mentioned by Moustakas (1994) so that it was completely open, receptive and naïve in listening to research participants' description of their PSR activities in labour standards and health \& safety. It meant refrained from judgments and abstained from ordinary way of perceiving things. The second process was phenomenological reduction. This process called for suspension of judgment as to the existence or nonexistence of an experience's content. It was an attempt to place the common sense and scientific knowledge about the phenomena with parentheses in order to achieve an unprejudiced description of the phenomena essence (Kvale, 1996). The third process was imaginative variation. The process of imaginative variation was "to seek possible meaning through the utilisation of imagination, varying the frames of reference, employing polarities and reversals, and approaching the phenomenon from divergent perspectives, different positions, roles, or functions" (Moustakas, 1994, pp. 97-98). The final step was synthesis of meanings and essences. It was the intuitive integration of the fundamental textural and structural descriptions into a unified statement of the essences of the experience of the whole phenomenon. Textural description wrote about what was experienced and structural description wrote about how the phenomenon was experienced (Moustakas, 1994).

\subsection{Research Question}

The data was collected from participants by using open-ended questions. Main question guiding this study was what is the experience of purchasing managers with regard to PSR activities in labour and health \& safety?

\subsection{The Sample}

The sample in this study was 16 purchasing managers worked in northern Malaysia. The major industrial areas in northern Malaysia were Penang and Kulim Hi-tech Park and thus the participants were selected from these two industrial areas. The sampling frame was obtained from the Federation of Malaysian Manufacturers (FMM) directory 2012; invest Penang Directory website and Kulim Hi-tech Park website. The researcher selected the purchasing managers from the electrical and electronics companies listed in these three directories. The research scope focuses on electrical and electronics (E \& E) industry in Penang and Kulim Hi-tech, Malaysia because this $\mathrm{E} \& \mathrm{E}$ industry is the biggest industry contributing to almost $45 \%$ of total export in Malaysia for both year 2011 and 2012 (MITI, 2012). Purposive sampling was done in this research to select 16 participants (purchasing managers) who worked in companies which use supplier code of conduct as a tool to manage suppliers' labour standard and health \& safety. This purposive sampling was chosen because not all companies in Malaysia could fit in this new research topic in Malaysia (Silverman, 2005). On top of this the time constraint will not allow the researcher to conduct in-depth interview for every existing example (Silverman, 2005). The participants were selected from electrical and electronics companies in Penang and Kulim Hi-tech Park with at least one year experience in PSR activities of labour, health and safety. In order to gain rich information, the sample was taken from multinational corporations with ownership and corporate headquarters from United States, Japan, German and Switzerland. Moreover, they are selected from original equipment manufacturers and contract manufacturers / electronics manufacturing services (EMS). The sample consisted of more American corporations because most of them managed to meet sample selection criteria. However, not many German, Japanese or other types of companies are able to meet the sample selection criteria.

\subsection{The Data}

The data was collected in a six months period from January until June 2014. Each in-depth interview lasted about 30 minutes.

The in-depth interviews consisted of three open ended guiding questions. The first question was designed to explore the extent of purchasing managers' involvement with regard to PSR activities in labour, health and safety. The second question was designed to explore the experience of purchasing managers with regard to supplier violations of labour, health and safety. The third question was asked pertaining to the issues experienced by purchasing managers while implementing PSR activities with suppliers. The pilot study was done with three participants and it indicated that the overall effect was consistent with the research objectives. After the pilot study, minor amendments were done on the interview questions to improve the flow of the interview process.

\section{RESULTS}

This study was divided into three main questions. The first main question explored the extent of purchasing managers' experience with regards to PSR activities in labour and health \& safety. The second question explored the issues experienced by purchasing while implementing PSR activities in labour and health \& safety. The third question explored the experience of purchasing managers pertaining to supplier violations in labour and health \& safety. 


\subsection{The Extent of PSR Activities}

The four themes emerged from the extent of PSR activities experienced by purchasing managers included PSR activities is enhanced by EICC membership but labour standards is new and less prioritised than health and safety, supplier audit is the most common PSR activity conducted for critical suppliers, supplier Self assessments triggers onsite audits or improvement plans, labour, health and safety are important criteria for supplier selection but only basic compliance is required. Each of these themes is explained clearly in the following paragraphs.

PSR activities were enhanced by EICC membership but labour standards were new and less prioritised than health and safety. The participants who involved actively in PSR activities were the ones worked in companies with EICC membership. The EICC code adopted by them had enhanced and enriched their experience with regards to PSR activities in labour, health and safety. They kept mentioning about EICC code when they explained PSR activities. Most of these participants involved actively in PSR activities which included supplier self-assessment, supplier audits, supplier selection and supplier training. In contrast, most participants who worked in companies without EICC membership did not involve much in PSR activities. Table 1 shows that $91 \%$ (10/11) of purchasing managers who work in organizations with EICC membership experienced PSR activities with the focus on labour, health and safety. However, for those purchasing managers who work in organisation without EICC membership, 83\% (5/6) of them just experience PSR activities with the focus on health and safety only without labour standards. This table also shows that $73 \%$ of American companies are members of EICC.

Table 1. The effect of EICC membership on labour, health and safety

\begin{tabular}{|c|l|c|c|c|}
\hline Participant & \multicolumn{1}{|c|}{ Company Type } & EICC Membership & Health \& Safety & Labour standards \\
\hline 1 & American OEM & No & Yes & No \\
\hline 2 & American CM & No & No & Yes \\
\hline 3 & American CM & Yes & Yes & Yes \\
\hline 4 & American OEM & Yes & Yes & No \\
\hline 5 & American OEM & Yes & Yes & Yes \\
\hline 6 & American OEM & Yes & Yes & Yes \\
\hline 7 & Japanese OEM & Yes & Yes & Yes \\
\hline 8 & German OEM & No & Yes & Yes \\
\hline 9 & American OEM & Yes & Yes & Yes \\
\hline 10 & American OEM & Yes & Yes & No \\
\hline 11 & German OEM & Yes & Yes & No \\
\hline 12 & Japanese OEM & No & Yes & Yes \\
\hline 13 & American CM & No & Yes & Yes \\
\hline 14 & American OEM & Yes & Yes & Yes \\
\hline 15 & American OEM & No & & \\
\hline 16 & Swiss OEM & & & \\
\hline
\end{tabular}

The research found that most purchasing managers in American companies of original equipment manufacturers (OEM) are more experienced in PSR activities compared with other types of companies. In contrary, the purchasing managers who work in American contract manufacturer (CM) companies are not so experienced in PSR activities. The reason being the products of American contract manufacturers are not visible in supplier factories. In addition, their priority as contract manufacturer is on price competitiveness rather than labour issues.

Table 2. Participants' experience with regard to PSR activities in labour, health and safety

\begin{tabular}{|l|c|c|}
\hline \multicolumn{1}{|c|}{$\begin{array}{c}\text { Experience with regard to PSR } \\
\text { activities }\end{array}$} & $\begin{array}{c}\text { Number of } \\
\text { participants }\end{array}$ & Percentage \\
\hline Health and safety standards & 15 & $94 \%$ \\
\hline Labour standards & 11 & $69 \%$ \\
\hline Only Health \& Safety standards & 5 & $31 \%$ \\
\hline Only labour standards & 1 & $6 \%$ \\
\hline All labour, health and safety standards & 10 & $63 \%$ \\
\hline
\end{tabular}

The level of participants' experience in PSR activities was different between labour, health and safety standards. Health and safety standards are given higher priority than labour standards. Kindly refer to Table 2 to see that 15 out of 16 participants (94\%) experienced PSR activities in health and safety but only 11 participants out of 16 participants $(69 \%)$ experienced labour standards. There were 5 participants who only experienced PSR activities in health and safety but not labour standards. However, only one participant experienced PSR activities in labour standards without health and safety standards. Anyway, there were 10 participants who experienced the full focus of labour, health and safety. PSR activities with the focus of labour were very new to most of the participants and they just started to experience them three years ago. Actually they just started PSR activities in labour standards when they adopted EICC code. However, the participants were exposed to health \& safety about ten years ago under environmental standards. That means participants were new to PSR activities related to labour standards such as child labour, wages and working hours. However, they were more experienced with regard to PSR activities related to health \& safety such as occupational safety, emergency preparedness, and industrial hygiene. 

Supplier audit was the most common PSR activity conducted for critical suppliers. Supplier audit was a PSR activity experienced by the $75 \%$ participants. However, they could not manage to audit all suppliers and thus they just identified critical suppliers who were new, high risks, labour intensive, and high spending value to be audited. The high risks suppliers might be triggered from supplier selfassessment report. High risks suppliers also included those suppliers from high risk countries with previous labour violations. The audits were done every two to three years for duration of 1-2 days. The audits were informed to suppliers two to three months in advance. Most of the times, participants joined the supplier audit together with the personnel from corporate headquarters, third party auditors, and other related department such as quality department, CSR department or health \& safety departments. However, minority of participants did not involve directly in on-site audits but they just make coordination or arrangement with suppliers and the auditors. Some of the participants sent their subordinates to involve in supplier audits but they provided them with the leadership and guidelines.

Supplier self-assessments triggered on-site audits or improvement plans. Supplier assessment is experienced by half of the total participants. It is a standard self-assessment questionnaire for suppliers to assess their own labour practices Supplier self-assessment was a PSR activity commonly experienced by more than half of the participants in this research. In fact it was one of the requirements for EICC code of conduct and the minimum requirement in PSR activities. Purchasing managers would not select any suppliers refused to participate in self-assessment or fail in the scores of self-assessment. It was done in a yearly basis and once every two years. Self-assessment produced compliance gaps and scores which could trigger corrective actions or on-site supplier audit. Self-assessment also provided opportunity for suppliers to improve before subsequent PSR activities were carried out. Participants worked with suppliers in order to upgrade their labour, health and safety standards based on the results from supplier self-assessment.

Labour, health and safety are important criteria for supplier selection but only basic compliance is required. Half of the 16 participants experienced incorporating labour and health \& safety as the criteria for supplier selection. However, only basic compliance is required for suppliers to be selected because not many suppliers are able to meet the full requirement of labour, health and safety standards. In fact some participants just asked some basic questions related to labour standards but did not do on-site audits or documents audits for verification. If suppliers could not meet the basic requirement of labour, health and safety standards, then they would not be selected. The participants would then select other suppliers who could meet these minimum requirements. Some participants required new suppliers to do self-assessment and they would not be selected as suppliers if their scores were too low. Unless there were no other alternative suppliers, otherwise the participants preferred not to select high risk suppliers in term of labour and health \& safety. In the event there were no alternative suppliers, then the participants ensured that suppliers improved their labour standards soonest within a scheduled time frame.
There were 7 out of the total 16 participants $(38 \%)$ experienced implementing short supplier training in labour, health and safety. Majority of the supplier training ranged from one hour to four hours. Supplier training was conducted for almost all suppliers at the same session or several sessions for different groups of suppliers. The supplier training was done quarterly or every 2 to 3 years. Supplier trainings cover guidelines, targets and objectives of labour, health and safety standards. A minority of participants did not perform the supplier training by themselves but just made arrangement for suppliers to be briefed by corporate people or CSR manager.

There were $38 \%$ of participants (6) who experienced supplier contracts which incorporated with labour, health and safety standards. The supplier contract would be signed by suppliers once they had gone through supplier selection. The contract was renewed every two to three years.

\subsection{Correction action to manage supplier violations in labour, health \& safety}

There were 4 participants $(25 \%)$ out of the 16 participants experienced supplier violation in safety shoes, safety equipment and other safety issues. Safety shoes and safety equipment violations included workers wore slippers, did not wear safety shoes and not using protective equipment while handing hazardous gas. Safety issues included workers did not follow standard procedures or not using proper tools. In addition, there were safety issues of not having fire service inspection certificate and electricians not having valid licenses.

There were $19 \%$ (3 participants) of participants experienced violations in emergency door, holding worker passports, working hours, wages and worker dormitories. Violations of emergency door included no exit point, lacked of exit doors, blockage of emergency door or access door not fully proof. Participants experienced the difficulty of suppliers not to hold worker passports as they did this in order to prevent migrant workers from running away because they paid high charges to obtain their work permit and travelling charges from their home countries. Working hour violation experiences with suppliers included overtime hours, not able to follow 60 working hours and overseas suppliers did not keep working hour record for workers. Also suppliers did not pay wages on time, could not follow minimum wage set by government or suppliers in overseas did not keep payroll records. Worker dormitory violations consist of overcrowd dormitory with more than 12 workers in a room and cooking is done in the room, no fire alarm, no siren or no fire drill.

Majority of the participants (44\%) experienced issuing corrective actions to suppliers and then worked with them to eliminate the violations or reduced them to the minimal level. The correction actions included issuance of noncompliance reports, corrective action reports or instruction for improvement. There are major or minor non-compliance reports depending on the seriousness of violations. Only $19 \%$ of the participants terminated the current suppliers due to the labour violations. For those potential suppliers who violated the labour requirement, only $13 \%$ of the participants disqualified them to be selected as suppliers. The participants chose to issue corrective actions instead of terminating suppliers because labour standards are new 
phenomenon for suppliers and not many of them could have high adherence to them. The participants might end up with very small number of suppliers if they did not maintain or select them. Thus they have to select these suppliers but work with them to upgrade their labour standards with a schedule time frame.

\subsection{Issues Experienced With Suppliers}

There were $19 \%$ (3 out 16) of participants experienced the issues of material price increase from suppliers. The material price increase from suppliers was caused by following the minimum wage set by government or extra cost incurred by improving workers' labour and health \& safety standards. Suppliers might deduct other intangible benefits given to workers in order to compensate the wage increase.

There were $19 \%$ of participants experienced the issues that workers of suppliers were in favour of overtime work because of additional wages. There were cases of workers leaving for another company in order to earn higher wages from overtime work. At times participants required their suppliers to increase working hours in order to meet their material delivery.

There were $19 \%$ participants who experienced the issue of suppliers reluctant to follow their labour, health and safety standards. Some suppliers had their own standards and this caused them reluctant to follow the standards given by participants. Also some suppliers felt that there were not value-added to follow labour, health and safety standards. Suppliers are reluctant to follow participants' labour, health and safety standards because apart from participants, they are not required by other customers.

\section{DISCUSSION AND IMPLICATION}

This research found that PSR activities were enhanced by EICC membership but labour standards were new and less prioritized than health and safety. In fact, some participants did not experience PSR activities in labour at all instead just experienced health and healthy. In addition, for those purchasing managers who experienced PSR activities in labour standards, they just experienced them for less than three years. These findings are similar with a PSR research in Korea which mentioned that social standards were still not popular and rarely implemented in electronics sector (Ki-Hoon \& Ji-Whan, 2009). Pertaining to the finding of EICC membership that enhances PSR activities, this is quite a new finding which was not mentioned by previous empirical research. The finding of supplier audit is the most common PSR activity conducted for critical suppliers is slightly different with previous research. Previous research did find supplier audit as a common PSR activity but it is done for all major suppliers instead of critical suppliers only. Supplier self-assessment triggers on-site audits or improvement plans is a new finding not mentioned in previous research. The previous research (Johnson, 2004; Maria, 2010) also did not mention this supplier selfassessment as one of the common PSR activities. However, supplier self-assessment is quite a common PSR activity found in this research to trigger site audit and improvement plans based on its results. This is especially relevant for companies with EICC membership because it is strongly encouraged by EICC. This research found labour, health and safety are important criteria for supplier selection but only basic compliance is required. It means that labour, health and safety are criteria for supplier selection but they are sufficient with basic requirement. In fact, this research found that some suppliers are selected after they answered some basic questions related to their labour conditions. In the event the purchasing managers needed a potential supplier's service but the supplier could not meet the requirement, the purchasing managers will select them with the condition that they improve the labour standards gradually. Supplier selection is mentioned as one of the important PSR activities in previous researches. However, the basic labour requirement for supplier selection is unique in Malaysia scenario and it was not mentioned in previous researches. Perhaps this is due to PSR activities in labour standards are new in Malaysia and not many potential suppliers are qualified to meet the labour standards.

The research found that corrective actions were used to manage labour violations of suppliers in occupational safety, working hours, wages, migrant dormitories, and holding migrant passports. Termination of suppliers was rarely implemented unless suppliers refuse to upgrade labour requirements. The abovementioned labour violations in this research align with previous research in Malaysia but there were not as serious as found in previous researches. For example, violation in wage was mostly related to minimum wage but no cases of non-payment of wages, delay of payment or wage reduction as reported in previous researches. Also this research did not find any issues of termination or work permit for migrant workers as mentioned in previous research (Amnesty, 2010Amnesty, 2010; Bormann, et al., 2010). Physical abuse or sexual harassment was not found in this research unlike what mentioned by Amnesty (2010). Violation for not having freedom of association by joining worker unions was not mentioned by purchasing managers. It is not because there is no violation in freedom of association but purchasing managers think that it is not crucial to emphasize on this since government does not allow E\&E companies to set up worker unions. It was very clear in this research that most purchasing manager will use corrective actions to work together with suppliers to resolve or eliminate their labour violations. Corrective actions are used instead of terminating suppliers or disqualifying potential suppliers. The corrective actions included issuance of non-compliance reports, corrective action reports or instruction for improvement. This corrective action was also mentioned by Johnson (2004) and is similar to draw up improvement plans mentioned by Maria (2010). Termination of suppliers is only done at the last resort when suppliers refused to improve labour requirements. The reason being PSR activities in labour standards are new phenomenon and thus not many suppliers could fully adhere accordingly. Otherwise, purchasing managers might end up with very few suppliers to supply them with the materials.

This research had similar finding with Welford \& Frost (2006) which mentioned that workers preferred longer working hours with overtime so that they could earn higher incomes. However, it is interesting to find the workers left the company when there was no overtime work, but this was not mentioned by Welford \& Frost (2006). In addition the issue of suppliers increase material price due to minimum wage was related to what Welford \& Frost (2006) 
mentioned as costly though the research did not specify about material price increase. The finding of suppliers reluctant to follow the requirement of labour, health and safety standards because it was not requested by most of their customers, this is a unique finding rarely mentioned by previous research in Asia.

This research found that the purchasing managers from American owned companies are more involved in PSR activities compared with other purchasing managers from Japanese, German and Swiss owned companies. This result is in line with the previous research in Malaysia which found that green supply chain initiatives differed between types of ownership (Eltayeb \& Zalaini, 2009)

The purchasing managers' experience in PSR activities shared in this study add significant value to purchasing managers, company stakeholders and electrical \& electronics industry. Based on this research results, PSR activities in labour standards were new phenomenon experienced by purchasing managers of electrical and electronics industry in Northern Malaysia. Thus, this experience of PSR activities in labour, health and safety are very useful and they will inspire many purchasing managers in Malaysia or other Asian countries who have yet to experience PSR activities. The finding of this research provides valuable benchmarking for purchasing managers in both multinational corporations and SMEs so that they could initiate or implement PSR activities in labour, health and safety. This research was done for purchasing managers from electrical and electronics industry. Therefore, the finding of this research is important for the review and improvement plans of electrical and electronics industry in this Asian region. Since all the participants in this research work in electrical \& electronics multinational corporations with corporate headquarters in United States, Japan, German and Switzerland, these study findings are worthwhile for the review and improvement plans of the corporate headquarters. This could be helpful for their comparison with their sister companies or branches in other regions or countries.

There is lack of PSR activities research to be conducted in qualitative phenomenological approach because most of the previous qualitative researches in PSR activities were done in case study approach (Johnson, 2004; Maria, 2010). This research contributes to qualitative phenomenological research by studying the lived experience of purchasing managers with regard to PSR activities in labour, health and safety.

\section{LIMITATION AND FUTURE RESEARCH}

The data was collected using phenomenological indepth interviews from 16 purchasing managers with experience pertaining to PSR activities with a focus in labour, health and safety. However this sample size of 16 participants was acceptable for a qualitative phenomenological study (Creswell, 2012). The purchasing managers were limited from electronics and electrical multinational companies in Northern Malaysia who agreed to participate voluntarily. As such the findings could not be used to generalize the experience of purchasing managers in other locations or other sector of industries. The data may differ if this study had included other industries or other countries. However, the objective of this phenomenological research is not generalisation; it is description of the lived experience. Also the accuracy of the interview responses could affect the interpretations of data analysis since participants' experience and expressions were central to research results and conclusions. In addition, validity of this study is limited to the honest, fair and balance account shared by participants (Neuman, 2011). Despite these limitations, this study shares useful experience of PSR activities for purchasing managers in northern Malaysia with a focus in labour, health and safety

This qualitative research serves as a starting point for further empirical study on the purchasing managers' experience with regard to PSR activities in Asian region. This research focuses on purchasing managers working in northern region of Malaysia, therefore, further research may include purchasing managers work in other locations of Malaysia, such as central Malaysia or southern Malaysia. In addition, future research can include other individual countries in Southeast Asia which such as Indonesia, Vietnam, Philippines, Brunei or Singapore.

Currently, PSR activities in labour, health and health are new phenomenon in Malaysia and only quite a small number of companies implementing PSR activities, future research could be conducted in quantitative methods to cover more companies in order to support or counter the findings of this study. Moreover, since currently PSR activities in labour are not common for smaller companies or SMEs in Malaysia, this research only included foreign multinational companies, future research could be conducted for local owned companies or SMEs. This PSR activities research focuses on labour, health and safety, future research in Malaysia could focus on other dimensions of PSR, for example diversity which is still lack of study.

\section{REFERENCES}

Amnesty, I. (2010). Trapped: The exploitation of migrant workers in Malaysia [Online]. Available in https://www.amnesty.org/en/library/asset/ASA28/002/2010/e n/114eba25-6af5-4975-9ea3-

02c22f6bdc5a/asa280022010en.pdf. Accessed: 23.06.2015.

Andersen, M., \& Skjoett-Larsen, T. (2009). Corporate social responsibility in global supply chains. Supply Chain Management: An International Journal, 14(2), pp.75-86.

Antonio, K. W. L. (2011). The implementation of social responsibility in purchasing in Hong Kong/Pearl River Delta: A case study. [DOI: 10.1108/17538291111108417]. Strategic Outsourcing: An International Journal, 4(1), pp.1346.

Bormann, S., Krishnan, P., Neuner, M., Rassbach, B., Sanghi, S., Latza, J., (2010). Migration in a Digital Age[Online]. Available in: http://electronicswatch.org/migration-in-adigital-age_3542.pdf. Accessed: 23.06.2015

Carter, C. R., \& Jennings, M. M. (2000). Purchasing's contribution to the socially responsible management of the supply chain. Center for Advanced Purchasing Studies, Tempe, AZ.

Carter, C. R., \& Jennings, M. M. (2004). The role of purchasing in corporate social responsibility: a structural equation analysis. Journal of Business Logistics, 25(1), pp.145-186.

Creswell, J. W. (2007). Qualitative inquiry \& research design: Choosing among five approaches: Sage Publications, Inc.

Ciliberti, F., Baden, D. \& Harwood, I.A. (2009). Insights into corporate social responsibility practices in supply chains: a multiple case of SMEs in the UK. Operations and Supply Chain Management 2(3), pp.154-166. 
Devadason, E. (2011). Policy Chaos Over Migrant Workers in Malaysia. East Asia Forum, January $11^{\text {th }}$ [Online]. Available in: http://www.eastasiaforum.org/2011/01/11/policy-chaosover-migrant-workers-in-malaysia/. Accessed: 23.06.2015

Devadason, E. S., \& Meng, C. W. A Critical Appraisal of Policies and Laws Regulating Migrant Workers in Malaysia[Online]. Available http://www.researchgate.net/publication/228434568_Policies _and_Laws_Regulating_Migrant_Workers_in_Malaysia_A_ Critical_Appraisal. Accessed: 23.06.2015

EICC. Electronic Industry Citizenship Coalition Code[Online]. Available in: http://www.eicc.info/documents/EICCCodeofConductEnglis h.pdf. Accessed: 23.06.2015

Eltantawy, R. A., Fox, G. L., \& Giunipero, L. (2009). Supply management ethical responsibility: reputation and performance impacts. Supply Chain Management: An International Journal, 14(2), pp.99-108.

Eltayeb, T.K., \& Zalaini, S. (2009). Going green through green supply chain initiatives towards environmental sustainability. Operations and Supply Chain Management 2(2), pp.93-100.

Hill, D. P. (2012). Port reform, South Asian migrant workers and spaces of vulnerability in Port Klang, Malaysia. Asia Pacific Viewpoint, 53(2), pp.105-117.

Jiang, B. (2009). Implementing supplier codes of conduct in global supply chains: Process explanations from theoretic and empirical perspectives. Journal of business ethics, 85(1), pp.77-92.

Johnson, M. (2004). Marks \& Spencer implements an ethical sourcing program for its global supply chain. Journal of Organizational Excellence, 23(2), pp.3-16.

Kanapathy, V., \& Office, I. L. (2008). Controlling irregular migration: The Malaysian experience: ILO.

Ki-Hoon, L., \& Ji-Whan, K. (2009). Current status of CSR in the realm of supply management: the case of the Korean electronics industry. [DOI: 10.1108/13598540910942000]. Supply Chain Management: An International Journal, 14(2), pp.138-148.

King, N., \& Horrocks, C. (2010). Interviews in qualitative research: Sage Publications Ltd.

Kvale, S. (1996). Interviews: An introduction to qualitative research interviewing: Sage Publications, Inc.

Lillywhite, S. (2007). Ethical Purchasing and Workers' Rights in China: The Case of the Brotherhood of St Laurence. Journal of Industrial Relations, 49(5), pp. 687-700.
Maignan, I., Hillebrand, B., \& McAlister, D. (2002). Managing Socially-Responsible Buying:: How to Integrate Noneconomic Criteria into the Purchasing Process. European Management Journal, 20(6), pp.641-648.

Maignan, I., \& McAlister, D. T. (2003). Socially Responsible Organizational Buying: How Can Stakeholders Dictate Purchasing Policies? [Article]. Journal of Macromarketing, 23(2), pp.78-89.

Malaysia, B. C. (2009). Migrant Workers Rights Multi Stakeholder Roundtable Discussion.

Maria, B. (2010). Benchmarking tool for improved corporate social responsibility in purchasing. [DOI: 10.1108/14635771011049335]. Benchmarking: An International Journal, 17(3), pp.340-362.

MITI. (2012). Export by major products. http://portaluat.miti.gov.my/cms/content.jsp?id=com.tms.cms .article.Article_f0f32c99-c0a8156f-42084208-. Date of accessed: 23/6/2015.

Moustakas, C. E. (1994). Phenomenological research methods: Sage Publications, Inc.

Nike, I., Corporate Responsibility Report FY07-09. (2007-9). Corporate Responsibility Report FY07-09. 73.

Patton, M. Q. (2002). Qualitative research and evaluation methods: Sage Publications, Inc.

Silverman, D. (2005). Doing qualitative research: A practical handbook: Sage Publications Ltd.

Spence, L., \& Bourlakis, M. (2009). The evolution from corporate social responsibility to supply chain responsibility: the case of Waitrose. Supply Chain Management: An International Journal, 14(4), pp.291-302.

Taves, A. (2003). Detachment and Engagement in the Study of" Lived Experience". Spiritus: A Journal of Christian Spirituality, 3(2), pp186-208.

Wahyono, S. (2005/2006). THE PROTECTION OF MIGRANT WORKERS'RIGHTS: EXPERIENCES IN MALAYSIA AND LEARNING FROM THE PHILIPPINES. Are We Up to the Challenge?, 1. http://www.api-

fellowships.org/body/international_ws_proceedings/year5.pd f. Date of accessed: 23/6/15.

Welford, R., \& Frost, S. (2006). Corporate social responsibility in Asian supply chains. Corporate Social Responsibility and Environmental Management, 13(3), pp.166-176.

Loo Saw Khuan is a senior lecturer of the School of Business Administration at Wawasan Open University, Malaysia. She is a PhD candidate in Management from University of Science, Malaysia. She received Master of Business Administration from Heriot-Watt University, United Kingdom and Bachelor of Social Science degree from University of Science, Malaysia. She has over 17 years industrial experience and six years teaching experience in supply chain. Her research interests include supply chain and purchasing social responsibility.

Ellisha Nasruddin is senior lecturer of Graduate School of Business at University of Science, Malaysia. She received PhD degree in Technology and Quality Management from Universiti Utara Malaysia and Master of Science from University of Bradford, United Kingdom. Her research interest include interlink operations management with ethics within an organizational transformation setting. 